\title{
Exploring Quorum Sensing Loci and Biofilm Formation in Bacillus Isolates from Pigeonpea Rhizosphere
}

\author{
K.P. Smitha*, E. Rajeswari, D. Alice and T. Raguchander \\ Department of Plant Pathology, Centre for Plant Protection Studies, Tamil Nadu Agricultural \\ University, Coimbatore-3, Tamil Nadu, India \\ *Corresponding author
}

\section{A B S T R A C T}

\begin{tabular}{|l|}
\hline Ke y w o r d s \\
Biocontrol, Pigeonpea, \\
Wilt, Root rot, \\
Quorum sensing, \\
Biofilm. \\
\hline Article Info \\
\hline Accepted: \\
24 September 2017 \\
Available Online: \\
10 November 2017 \\
\hline
\end{tabular}

\section{Introduction}

Bacillus is an omnipresent spore-forming gram positive bacterium with the ability to produce a number of lipopeptide molecules with wide range of antimicrobial properties. Bacillus has evolved as a successful biocontrol agent during the recent past owing to its strong antibiotic arsenal coupled with high rhizosphere fitness. The lipopeptides produced by Bacillus generally belong to the class of iturins, surfactin and fengycins which are highly surface active molecules (Ongena and Jacques, 2008).Success of a biocontrol agent is primarily dependent on its ability to colonize the plant rhizosphere. The basic requirement for plant root colonization by any bacteria is attachment and aggregation in microcolonies/biofilms (Kearns et al., 2004). Thecyclic lipopeptides of the surfactin family is involved in the formation of biofilm in Bacillus. The amphiphilic nature of surfactins accounts for their excellent surface activities.

The production of lipopeptide antibiotics is dependent upon the density of bacterial cells in a particular environment (Grossman, 1995; Msadek, 1999; Tortosa and Dubnau, 1999). High density cultures of Bacillus subtilis accumulates ComX pheromone molecules in the culture supernatant, which upon attaining a critical concentration triggers adaptive 
cellular responses like surfactin production and biofilm formation. In $B$. subtilis, production of degradative enzymes and antibiotics is a density dependent phenomena regulated by ComQXPA quorum sensing system (Schneider et al., 2002). The comQXPA operon controls multiple genes that govern important attributes expressed in the stationary growth phase (Grossman, 1995). Hence in the present study, the bacterial isolate $B$. subtilis $\mathrm{CcB} 7$ which showed potential antifungal activity was tested for its capacity to form biofilm in solid and liquid media and an attempt was made to detect the presence of quorum sensing genes and loci in the isolate.

\section{Materials and Methods}

\section{Bacillus cultures}

The cultures used in this study were isolated from pigeonpea rhizosphere soil by standard serial dilution technique and maintained on nutrient agar slants at $4^{\circ} \mathrm{C}$. A total of 18 Bacillus strains which showed potential in vitro inhibition of soil-borne fungal pathogens and growth promotion activities were screened for antibiotic production.

\section{DNA isolation and PCR amplification of lipopeptide antibiotic genes}

The genomic DNA was isolated from selected strains for antibiotic gene detection through PCR. Genomic DNA was isolated using the cetyltrimethyl ammonium bromide (CTAB) method described by Knapp and Chandlee (1996), with slight modifications (Melody, 1997).

The antibiotic genes surfactin, iturinA, iturin $\mathrm{D}$, fengycin and bacillomycin $\mathrm{D}$ were amplified using gene specific primers as detailed in Table 1.

\section{Primer designing and PCR amplification of quorum sensing genes}

Primer designing was done using the Primer3 softwareto detect the presence of quorum sensing genes viz., $\operatorname{com} Q, \operatorname{com} X, \operatorname{com} P$ and comA in the selected isolates. The genome sequence of B. subtilis subsp. subtilis str. 168 (GenBank accession No. NC000964.3) which showed 99\% homology with the promising rhizospheric Bacillus subtilis strain $\mathrm{CcB} 7$ was used for primer designing. From the whole genome sequence of NC000964.3, the region $3255900-3257092$ was used for designing primers for ComQ gene, 3256050 32555838 for ComX, 3255900 - 3253400 for ComP and 3253500 - 3252785 region for ComA gene. The sequences of the primers designed and the expected product size are given in Table 2. The primers were synthesized by Sigma-Aldrich.

The $40 \mu \mathrm{l}$ PCR reaction mixture contained DNA template $50 \mathrm{ng}, 1 \mathrm{X}$ Taq buffer, $0.2 \mathrm{mM}$ of each of dNTP mixture, $1 \mu \mathrm{M}$ of each primers, $1.5 \mathrm{mM} \mathrm{MgCl}_{2}$ and $2 \mathrm{U}$ of Taq DNA polymerase (Sigma). PCR amplification was performed in a Mastercycler using the conditions: Initial denaturation at $94^{\circ} \mathrm{C}$ for 3 min, 40 cycles consisting of $94^{\circ} \mathrm{C}$ for $1 \mathrm{~min}$ (denaturation), annealing temperature (specified in Table 2 for each gene) for $1 \mathrm{~min}$, $72^{\circ} \mathrm{C}$ for $1 \mathrm{~min}$ (primer extension) and final extension $72^{\circ} \mathrm{C}$ for $10 \mathrm{~min}$.

\section{PCR amplification and sequencing of quorum sensing loci com $Q X P$}

The entire $\operatorname{com} Q$ and $\operatorname{com} X$ genes and the first $1.7 \mathrm{~kb}$ of $\operatorname{comP}$ loci was amplified by PCR using the primer UnicomQ1 (5, GGGAGGGGGGAAGTCGTTATTG 3') and P1 (5' AAGAACCGAATCGTGGAGATCG CG 3') in a $20 \mu 1$ reaction mixture. The PCR profile of the comQXP locus amplification consisted of 30 cycles of denaturation at $94^{\circ} \mathrm{C}$ 
for $30 \mathrm{~s}$, annealing at $55^{\circ} \mathrm{C}$ for $45 \mathrm{~s}$, extension at $72^{\circ} \mathrm{C}$ for $3 \mathrm{~min}$, and final extension at $72^{\circ} \mathrm{C}$ for $5 \mathrm{~min}$ (Tortosa et al., 2001).

The comQXP gene was purified from each reaction mixture by agarose $(1.2 \% \mathrm{w} / \mathrm{v})$ gel electrophoresis in TAE buffer containing 0.5 $\mu \mathrm{g}$ of ethidium bromide per $\mathrm{ml}$. A small agarose slice containing the band of interest (observed under long-wavelength (312-nm) UV light) was excised from the gel and purified by using a QIA quick gel extraction kit (Qiagen, Inc., Chatsworth, California) according to the instructions of manufacturer. This purification was performed to remove primer dimers and other residues from the PCR product. The DNA sequencing was performed at Xcelris Genomics Pvt. Ltd. Ahmedabad, India.

\section{Microtitre plate assay of Bacillus subtilis biofilm formation}

Bacillus subtilis biofilm formation was monitored using a modified version of the microtitre plate assay as described by O'Toole et al., (1999). Bacillus subtilis cells were grown in biofilm growth medium (Luria - Bertani (LB) medium plus $0.15 \mathrm{M}$ ammonium sulphate, $100 \mathrm{mM}$ potassium

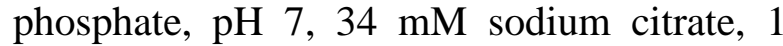
$\mathrm{mM} \mathrm{MgSO}_{4}$ and $0.1 \%$ glucose) with shaking to mid-exponential growth and adjusted to an OD600 of 0.01 in fresh biofilm growth medium. Samples of $100 \mu \mathrm{l}$ of the diluted cells were then pipetted to each well of a 96well PVC microtitre plate. The microtitre plates were incubated at $37^{\circ} \mathrm{C}$ under stationary conditions, cultures were mixed by pipetting up and down twice to oxygenate the medium at $12 \mathrm{~h}$ after inoculation. The spent growth medium was exchanged for fresh biofilm growth medium $12 \mathrm{~h}$ after mixing. This cycle of mixing followed by exchanging the medium every $12 \mathrm{~h}$ was repeated for the time course of the experiment. The presence of adhered cells was monitored by staining with crystal violet $(\mathrm{CV})$ at $48 \mathrm{~h}$ and $96 \mathrm{~h}$ after inoculation. Growth medium and nonadherent cells were removed from the microtitre plate wells followed by rinsing with wash buffer $(0.15 \mathrm{M}$ ammonium sulphate, $100 \mathrm{mM}$ potassium phosphate, $\mathrm{pH} 7$, $34 \mathrm{mM}$ sodium citrate, $1 \mathrm{mM} \mathrm{MgSO}_{4}$ ). Cells adhered to the wells were stained with $1 \% \mathrm{CV}$ in wash buffer at room temperature for 20 min. Excess CV was then removed, and the wells were rinsed with water. The $\mathrm{CV}$ that had stained the cells was then solubilized in $200 \mathrm{ml}$ of $80 \%$ ethanol, $20 \%$ acetone. Biofilm formation was quantified by measuring the OD570 for each well using a Bio-Rad model 550 plate reader.

\section{Population dynamics of Bacillus spp in pigeonpea rhizosphere}

A pot experiment was designed to study the population dynamics of Bacillus in the pigeonpea rhizosphere. The experiment was conducted in completely randomized block design replicated three times and four pots were maintained for each replication. Surface sterilized seeds of pigeonpea (CoRg7) were sown in pots containing pathogen inoculated potting mixture at the rate of two seeds per pot. Six pots were maintained for each replication. Two B. subtilis isolates viz., CaB5 and EPCO16 and a standard chemical Carbendazim were also used as checks.

The treatments used are furnished below. One gram of rhizosphere soil was collected from treated plants at monthly interval till four months after sowing. The population dynamics of Bacillus was assessed through serial dilution technique at $10^{-6}$ dilution in Nutrient agar medium.

T1 - Seed treatment@10 g kg-1 + basal application of B. subtilis CcB7 @ 2.5 kg ha-1 T2 - Seed treatment @10 g kg-1 + basal 
application of B. subtilis CaB5 @ $2.5 \mathrm{~kg} \mathrm{ha}^{-1}$

T3 - Seed treatment @ $10 \mathrm{~g} \mathrm{~kg}^{-1}+$ basal application of B. subtilis EPCO16 @ $2.5 \mathrm{~kg}$ ha $^{-1}$

T4 - T1 + soil application of B. subtilis CcB7 @ $2.5 \mathrm{~kg} \mathrm{ha}^{-1}$ at $45 \mathrm{DAS}$

T5 - T2 + soil application of B. subtilis CaB5 @ $2.5 \mathrm{~kg} \mathrm{ha}^{-1}$ at $45 \mathrm{DAS}$

T6 - T3 + soil application of B. subtilis EPCO16@ $2.5 \mathrm{~kg} \mathrm{ha}^{-1}$ at 45 DAS

T7 - Seed treatment + soil drenching with carbendazim $0.1 \%$ at 45 DAS

$\mathrm{T} 8$ - $\mathrm{T} 1+$ carbendazim $0.1 \%$ soil drenching at 45 DAS

$\mathrm{T} 9$ - $\mathrm{T} 2+$ carbendazim $0.1 \%$ soil drenching at 45 DAS

$\mathrm{T} 10-\mathrm{T} 3+$ carbendazim $0.1 \%$ soil drenching at 45 DAS

T11 - Control

The population of Bacillus spp in all the treatments were enumerated by serial dilution technique at monthly interval up to 120 days.

\section{Statistical analysis}

All the experiments were analysed independently.

The treatment means were compared by Duncan's Multiple Range Test (DMRT).

The package used for analysis was IRRISTAT version 92-1 developed by the International Rice Research Institute Biometrics unit, The Philippines.

\section{Results and Discussion}

Screening of 18 promising isolates for the presence of lipopeptide antibiotic genes was done by PCR. The culture $\mathrm{CcB} 7$ tested positive for the presence of all the tested five antibiotic genes tested viz., surfactin, iturin A, iturin $\mathrm{D}$, fengycin $\mathrm{D}$, and bacillomycin $\mathrm{D}$ (Table 3). The bacterial isolate $\mathrm{CcB} 7$ was confirmed as Bacillus at the genus level based on the PCR amplification of the 16s rRNA using ITS primers BCF1 and BCR2 which yielded an amplicon size of approximately 546 bp. The partial sequence of 16s rRNA gene showed $99 \%$ similarity to B. subtilis strains in the NCBI database and therefore designated as $B$. subtilis strain $\mathrm{CcB}$. The sequence was submitted to GenBank with Accession No. KR265028.1.

\section{Amplification of quorum sensing genes}

PCR amplification using the primers designed for quorum sensing genes produced amplicons of size $544 \mathrm{bp}$ for ComQ, $175 \mathrm{bp}$ for ComX, $996 \mathrm{bp}$ for comP gene and $464 \mathrm{bp}$ for comA gene (Plate 1). The quorum sensing loci comQXP was amplified in Bacillus subtilis strain $\mathrm{CcB} 7$ by PCR using the forward primer UniComQ and the reverse primer P1. The amplicon size obtained was approximately $3 \mathrm{~kb}$ (Plate 2). The PCR product was excised from gel and purified using quick gel extraction kit and sequenced by Primer Walk at Xcelris Genomics Pvt. Ltd., Ahmedabad, India. The consensus sequence of $2775 \mathrm{bp}$ was generated from the sequence data obtained. Sequence homology searches performed using the BLAST program of NCBI revealed 94\% similarity with the quorum sensing locus of $B$. subtilis isolate RO-F-3 (AF456137). The comX gene was detected with a homology of $99 \%$ (e value $=0.00$ ) similarity to $B$. subtilis strain RO-F-3 quorum sensing gene locus and the protein translate revealed identity with ComX 
pheromone precursor. The comP gene sequence showed $95 \%$ similarity to $B$. subtilis strain RO-F-3 quorum sensing gene locus and the protein translate revealed identity with histidine kinase sensor protein. The $\operatorname{com} A$ gene sequence showed $98 \%$ similarity to comA gene of $B$. subtilis and the protein translate revealed identity with response regulation transcription factor. The nucleotide sequences of $\operatorname{com} X, \operatorname{com} P$ and $\operatorname{com} A$ have been deposited at the GenBank with accession numbers KT335526, KT335525 and KT335524 respectively.

\section{Assay on biofilm formation by Bacillus strains}

Bacillus subtilis strain $\mathrm{CcB} 7$ was found to form robust pellicles or floating biofilms and solid surface associated biofilms in standing culture (Plate 3). They formed highly structured colonies on agar medium that were strikingly mucoid in the centre (Plate 4). The formation of biofilm was also quantified by microtitre plate assay (Plate5). At 48 and $96 \mathrm{~h}$ after incubation, the OD values for the Bacillus subtilis strain CcB7 was 3.35 and
3.75 respectively which were significantly higher compared to other strains tested (Table 4).

\section{Population dynamics of $\mathrm{CcB} 7$ in rhizosphere soil}

Population dynamics study revealed that there was a gradual increase in the Bacillus spp population in all the treatments wherein Bacillus was amended (i.e. except carbendazim and untreated check). At 120 days after treatment, the population of Bacillus spp. was $78 \times 10^{8} \mathrm{cfu} / \mathrm{g}$ of rhizosphere soil treated with seed treatment @ $10 \mathrm{~g} \mathrm{~kg}^{-1}$ seed along with basal application of $B$. subtilis strainCcB7@ $2.5 \mathrm{~kg} \mathrm{ha}^{-1}$ followed by application of $\mathrm{CcB} 7$ at $45 \mathrm{DAS}\left(\mathrm{T}_{4}\right)$. This was significantly superior to the treatments which included single basal application of Bacillus spp. (Fig. 1). The results clearly indicate that there is enhanced Bacillus population in all treatments except standard chemical check and untreated control. It also indicates that the pigeonpea rhizosphere favoured $\mathrm{CcB} 7$ strains which were initially collected from the respective rhizosphere soil.

Table.1 Details of the primers used for amplification of antibiotic genes

\begin{tabular}{|c|c|c|c|c|c|}
\hline Antibiotic & $\begin{array}{c}\text { Primer } \\
\text { name }\end{array}$ & Primer sequence (5'-3') & $\begin{array}{c}\text { Annealing } \\
\text { temp. }\end{array}$ & $\begin{array}{c}\text { Amplicon } \\
\text { size (bp) }\end{array}$ & Reference \\
\hline Surfactin & $\begin{array}{c}\text { SUR3F } \\
\text { SUR3R }\end{array}$ & $\begin{array}{c}\text { ACAGTATGGAGGCATGGTC } \\
\text { TTCCGCCACTTTTTCAGTTT }\end{array}$ & $57^{\circ} \mathrm{C}$ & 441 & $\begin{array}{c}\text { Ramarathnam } \\
\text { et al., } 2007\end{array}$ \\
\hline Iturin A & $\begin{array}{c}\text { ITUD1F } \\
\text { ITUD1R }\end{array}$ & $\begin{array}{c}\text { GATGCGATCTCCTTGGATGT } \\
\text { ATCGTCATGTGCTGCTTGAG }\end{array}$ & $60^{\circ} \mathrm{C}$ & 647 & $\begin{array}{c}\text { Ramarathnam } \\
\text { et al., } 2007\end{array}$ \\
\hline Iturin D & $\begin{array}{c}\text { ITUD-F1 } \\
\text { ITUD-R1 }\end{array}$ & $\begin{array}{c}\text { TTGAAYGTCAGYGCSCCTTT } \\
\text { TGCGMAAATGGSGTCGT }\end{array}$ & $57^{\circ} \mathrm{C}$ & 482 & Chung et al., 2008 \\
\hline Fengycin D & $\begin{array}{c}\text { FEND 1F } \\
\text { FEND 1R }\end{array}$ & $\begin{array}{c}\text { TTTGGCAGCAGGAGAAGTTT } \\
\text { GCTGTCCGTTCTGCTTTTTC }\end{array}$ & $60^{\circ} \mathrm{C}$ & 964 & $\begin{array}{c}\text { Athukorala } \text { et al., } \\
2009\end{array}$ \\
\hline Bacillo- \\
mycin D & $\begin{array}{c}\text { BACC1F } \\
\text { BACC1R }\end{array}$ & $\begin{array}{c}\text { GAAGGACACGGCAGAGAGTC } \\
\text { CGCTGATGACTGTTCATGCT }\end{array}$ & $62^{\circ} \mathrm{C}$ & 875 & $\begin{array}{c}\text { Ramarathnam } \\
\text { et al., } 2007\end{array}$ \\
\hline
\end{tabular}


Table.2 Details of the primers designed for amplifying quorum sensing genes

\begin{tabular}{|c|c|c|c|c|}
\hline Gene & Primer & Description & $\begin{array}{l}\text { Annealing } \\
\text { Temp. }\left({ }^{\circ} \mathrm{C}\right)\end{array}$ & $\begin{array}{c}\text { Amplicon } \\
\text { size }\end{array}$ \\
\hline \multirow{2}{*}{$\operatorname{com} Q$} & Forward & GTC TTG CAT CTT GTA TCCC T & \multirow{2}{*}{63} & \multirow{2}{*}{$544 \mathrm{bp}$} \\
\hline & Reverse & ACG TAA ACG AGG CCA TGCAA & & \\
\hline \multirow{2}{*}{$\operatorname{com} X$} & Forward & TCA CCC CAT TGA CGG GTT T & \multirow{2}{*}{62} & \multirow{2}{*}{$175 \mathrm{bp}$} \\
\hline & Reverse & GGG GAT ACA AGA TGC AAG CC & & \\
\hline \multirow{2}{*}{$\operatorname{comP}$} & Forward & TCG CAA TCA AAA CCG CTT C & \multirow{2}{*}{62} & \multirow{2}{*}{$996 \mathrm{bp}$} \\
\hline & Reverse & GGA TCT GAA TCT AGG CGG CG & & \\
\hline \multirow{2}{*}{$\operatorname{com} A$} & Forward & CGC CTC GTT CAC CAA CTT TC & \multirow{2}{*}{61} & \multirow{2}{*}{$464 \mathrm{bp}$} \\
\hline & Reverse & TAA GTG CAG GCG GAC CAT TT & & \\
\hline
\end{tabular}

Table.3 PCR-based detection of antibiotics producing genes in the Bacillus strains

\begin{tabular}{|c|c|c|c|c|c|c|}
\hline S.No & Bacillus strain & Surfactin & Iturin A & Iturin D & Fengycin A & Bacillomycin D \\
\hline 1 & $\mathrm{CcB} 4$ & - & + & + & - & - \\
\hline 2 & $\mathrm{CcB} 7$ & + & + & + & + & + \\
\hline 3 & $\mathrm{CcB} 13$ & - & + & + & - & - \\
\hline 4 & $\mathrm{CcB} 14$ & - & + & + & - & - \\
\hline 5 & $\mathrm{CcB} 15$ & + & + & + & + & - \\
\hline 6 & $\mathrm{CcB} 17$ & + & - & + & - & - \\
\hline 7 & CcB20 & + & + & - & + & - \\
\hline 8 & $\mathrm{CcB} 27$ & + & - & + & + & - \\
\hline 9 & $\mathrm{CcB} 30$ & - & + & - & - & - \\
\hline 10 & $\mathrm{CcB} 33$ & + & + & - & - & - \\
\hline 11 & $\mathrm{CcB} 34$ & + & - & - & - & - \\
\hline 12 & $\mathrm{CcB} 37$ & + & - & + & - & - \\
\hline 13 & $\mathrm{CcB} 55$ & + & + & + & - & - \\
\hline 14 & $\mathrm{CcB58}$ & + & - & + & - & - \\
\hline 15 & CcB64 & - & - & + & - & - \\
\hline 16 & CcB68 & - & + & + & - & - \\
\hline 17 & CcB69 & - & - & + & - & - \\
\hline 18 & CcB96 & - & - & + & + & - \\
\hline
\end{tabular}
(+) Present
(-) Absent 
Table.4 Quantification of biofilm formation by Bacillus using Microtitre plate assay

\begin{tabular}{|c|c|c|}
\hline Bacillus strain & $\begin{array}{l}\text { OD Value at } 600 \mathrm{~nm} * \\
(48 \mathrm{~h} \text { after incubation) }\end{array}$ & $\begin{array}{l}\text { OD Value at } 600 \mathrm{~nm}^{*} \\
(96 \mathrm{~h} \text { after incubation) }\end{array}$ \\
\hline CcB4 & $2.20^{\mathrm{f}}$ & $3.73^{\mathrm{ab}}$ \\
\hline $\mathrm{CcB} 7$ & $3.35^{\mathrm{a}}$ & $3.75^{\mathrm{ab}}$ \\
\hline $\mathrm{CcB} 13$ & $1.81^{\mathrm{h}}$ & $2.65^{\mathrm{hi}}$ \\
\hline $\mathrm{CcB} 14$ & $2.16^{\mathrm{fg}}$ & $2.34^{\mathrm{j}}$ \\
\hline $\mathrm{CcB} 15$ & $2.33^{\mathrm{ef}}$ & $3.15^{\mathrm{ef}}$ \\
\hline $\mathrm{CcB} 17$ & $2.50^{\text {cde }}$ & $3.08^{\mathrm{efg}}$ \\
\hline $\mathrm{CcB} 20$ & $0.98^{\mathrm{n}}$ & $2.31^{j}$ \\
\hline $\mathrm{CcB} 27$ & $1.23^{\mathrm{Im}}$ & $3.23^{\mathrm{de}}$ \\
\hline CcB30 & $3.11^{b}$ & $3.46^{\mathrm{cd}}$ \\
\hline $\mathrm{CcB} 33$ & $2.65^{c}$ & $3.77^{\mathrm{ab}}$ \\
\hline $\mathrm{CcB34}$ & $2.43^{\mathrm{de}}$ & $2.89^{\mathrm{fgh}}$ \\
\hline $\mathrm{CcB} 37$ & $1.10^{\mathrm{mn}}$ & $2.42^{\mathrm{ij}}$ \\
\hline $\mathrm{CcB55}$ & $1.99^{\text {gh }}$ & $2.68^{\mathrm{hi}}$ \\
\hline CcB58 & $2.20^{\mathrm{f}}$ & $3.65^{\mathrm{bc}}$ \\
\hline CcB64 & $1.55^{\mathrm{ij}}$ & $2.83^{\text {gh }}$ \\
\hline CcB68 & $1.63^{\mathrm{ij}}$ & $1.76^{\mathrm{k}}$ \\
\hline CcB69 & $2.50^{\text {cde }}$ & $2.96^{\mathrm{efg}}$ \\
\hline CcB96 & $1.00^{n}$ & $2.64^{\mathrm{hi}}$ \\
\hline
\end{tabular}

*Values are mean of three replications

Means in a column followed by same superscript letters are not significantly different according to DMRT.

Plate.1 PCR amplification of ComA gene of 18 isolates of Bacillus

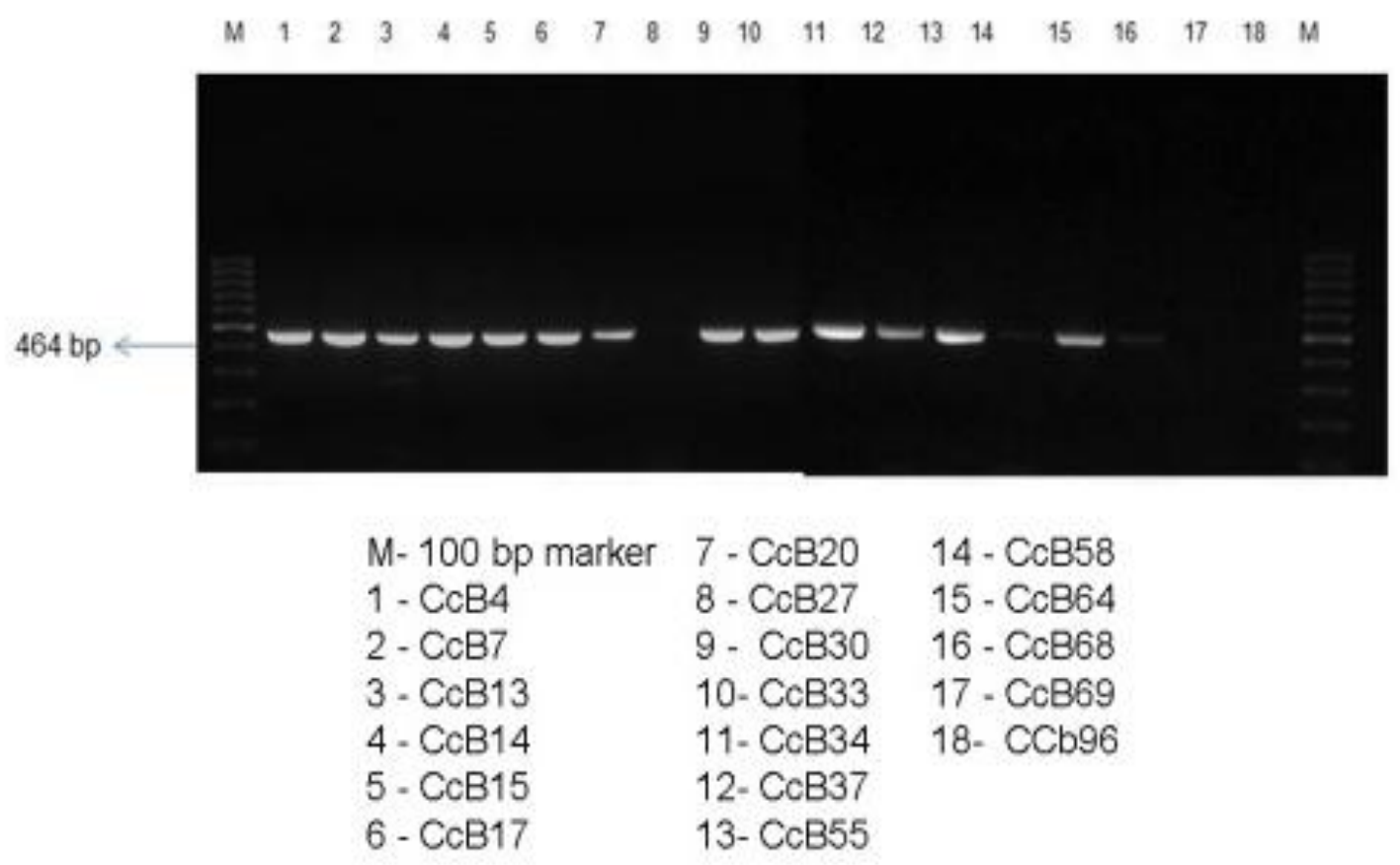


Plate.2 PCR amplification of ComQXP loci of B. subtilis strain CcB7

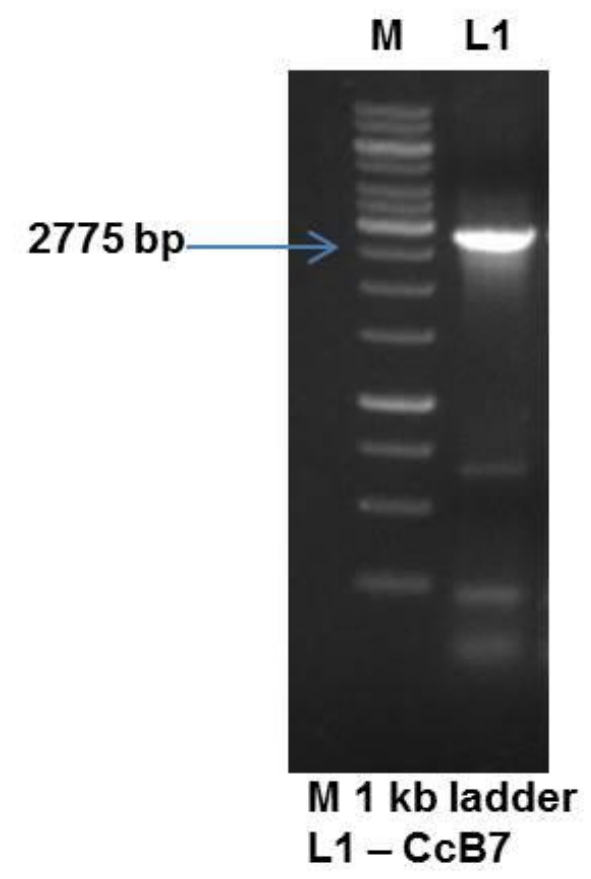

Plate.3 Pellicle formation by $B$. subtilis $\mathrm{CcB} 7$ in liquid media

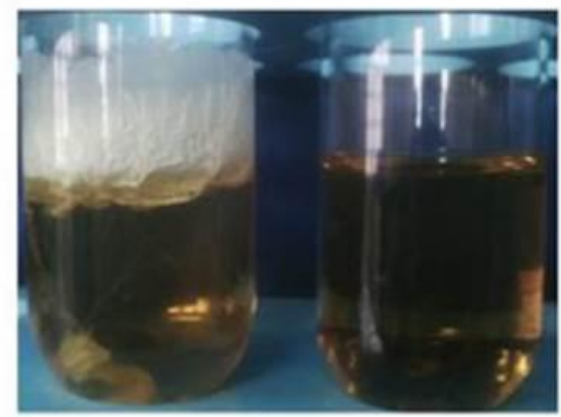

Bacillus subtilis CCB7 Control

Plate.4 Formation of robust biofilm on solid media
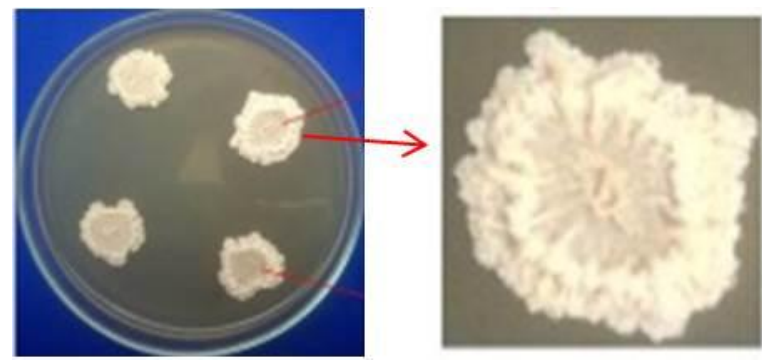

Bacillus subtilis CcB7 
Plate.5 Microtitre plate assay for quantifying biofilm formation

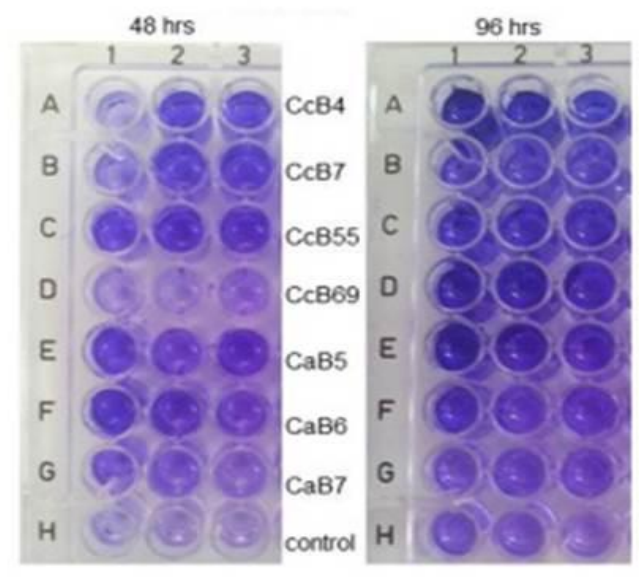

Intensity of violet colour is proportional to biofilm forming capability

Fig.1 Effect of formulation on the population dynamics of Bacillus spp. in pigeonpea rhizosphere

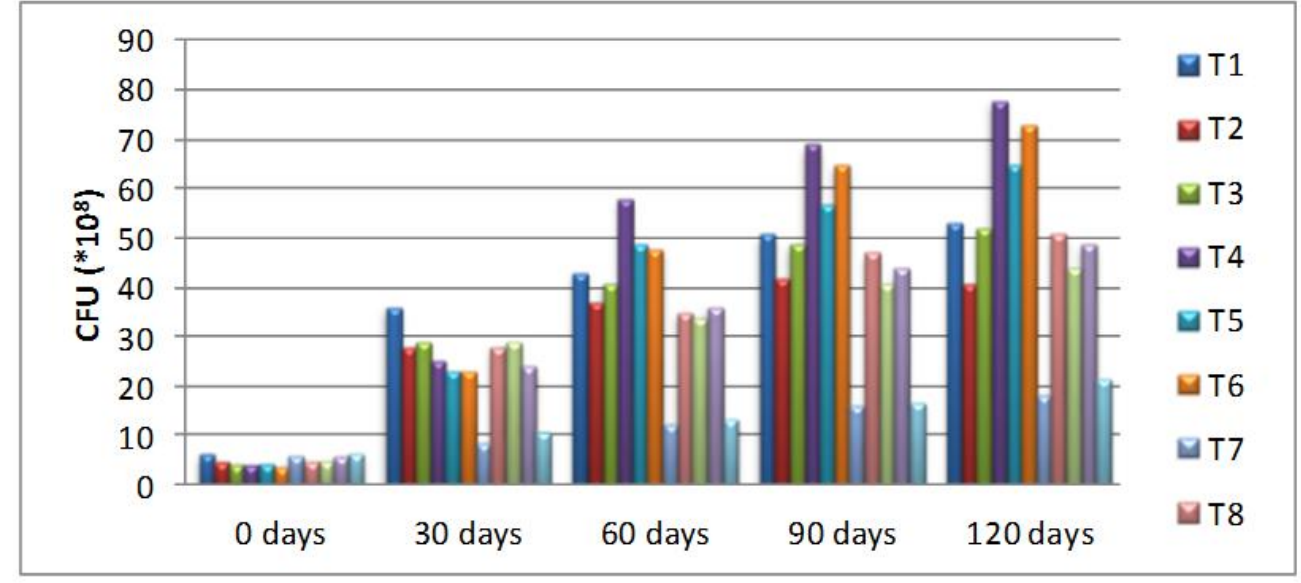

The use of Bacillus in the biological control of plant diseases is well documented (Asaka and Shoda, 1996; Narasimhan and Shivakumar, 2015). The colonization of plant organs that are infection sites for the pathogen is a key feature for biocontrol success (Mikiciński et al., 2016). Results of the present study showed that native Bacillus strain $\mathrm{CcB} 7$ was more efficient in colonizing the pigeonpea rhizosphere compared to strains isolated from other rhizospheres. An important trait of plant rhizobacteria is their ability to effectively colonize the rhizosphere and maintain a stable relationship with the surface of plant roots which again depends on their abilities to take advantage of a specific environment or on their abilities to adapt to changing conditions. The microorganisms isolated from the rhizosphere of a specific crop may show better adaptation to that crop and may provide better control of diseases than organisms isolated from other plant species. Such plant associated microorganisms make better biocontrol agents because they are already closely associated with and adapted to the plant and the particular environmental conditions in which they must function. The selection of bacterial strain having the potential to synthesis surfactin will facilitate in biofilm formation and better rhizosphere colonization thereby excluding the pathogens. Further 
production of antibiotics like iturin and fengycin will also inhibit the growth of pathogenic organisms.

In the present investigation, the Bacillus strain CcB7 formed highly structured colonies which indicated biofilm formation. Microtitre plate assay showed the adherence of bacterial cells to the plates indicating formation of biofilm by all Bacillus isolates. Quorum-sensing regulated biofilm formation allows the organism to create a niche, into which, it then secretes secondary metabolites protecting the rhizosphere. It is possible that surfactin and biofilm formation may allow $B$. subtilis to efficiently colonize plant roots and also provide protection to their host.

Previous studies have reported that by modifying cell surface properties, surfactin and iturin positively influence cell spreading, swarming and biofilm formation (Bais et al., 2004; Leclere et al., 2006) and thus may globally favour plant root colonisation. Bais et al., (2004) observed that lipopeptide production and biocontrol activity are directly related to the ability of $B$. subtilis to form stable biofilms on plant roots. Surfactin produced early in the growth cycle of the bacterium rapidly increase the surface motility and accelerates the development of multicellular communities called as biofilms (Rudrappa et al., 2008). The involvement of cyclic lipopeptides in biofilm formation by $B$. subtilis has been reported previously (Branda et al., 2001; Hofemeister et al., 2004). Nihorimbere et al., (2011) showed that surfactin synthesis by S499 cells forming biofilm is very effective compared to iturins and fengycins as observed or the cLP pattern secreted in planta. The development of Bacillus cells as root-adhering microcolonies may thus be a crucial factor to explain the differential production of the three cLP families. Saha et $a l$. , (2012) studied the biofilm formation by $B$. subtilis isolates $\mathrm{AI} 01$ and $\mathrm{AI} 03$ and found that the isolate AI01 was a more efficient producer of biofilm. They also noted that the level of adherence to polystyrene plates increased with increase in incubation period.
To conclude, the Bacilllus subtilis strain $\mathrm{CcB} 7$ isolated from the rhizosphere of pigeonpea was found to have three major antibiotic genes, viz., surfactin, iturin and fengycin and very good biofilm forming ability. It also survived well in the soil during the entire crop period and will definitely be an excellent biocontrol agent for reducing the incidence of root rot and wilt disease.

\section{Acknowledgement}

The authors gratefully acknowledge the funding from Department of Science and Technology, SERB, Government of India in carrying out this work. The authors also thankfully acknowledge the Department of Plant Pathology, Tamil Nadu Agricultural University, Coimbatore, India for providing laboratory facilities for carrying out the research work.

\section{References}

Asaka, O. and Shoda, M. 1996. Biocontrol of Rhizoctoniasolani damping off of tomato with Bacillus subtilis RB14. Appl. Environ. Microbiol.,62: 4081-4085.

Bais, H., Fall, R. and Vivanco, J. M. 2004. Biocontrol of Bacillus subtilis against infection of Arabidopsis roots by Pseudomonas syringae is facilitated by biofilm formation and surfactin production. Plant physiol., 134: 307-319.

Branda, S. S., Gonzalez-Pastor, J. E., BenYehuda, S., Losick, R. and Kolter, R. 2001. Fruiting body formation by Bacillus subtilis. Proc. Natl. Acad. Sci. U.S.A., 98: 11621-11626.

Grossman, A. D. 1995. Genetic networks controlling the initiation of sporulation and the development of genetic competence in Bacillus subtilis. Ann. Rev. Genet., 29: 477-508.

Hofemeister, J., Conrad, B., Adler, B., Hofemeister, B., Feesche, J., Kucheryava, N., Steinborn, G., Franke, P., Grammel, N., Zwintscher, A., Leenders, F., Hitzeroth, G. and Vater, J. 2004.Genetic 
analysis of the biosynthesis of nonribosomal peptide and polyketide-like antibiotics, iron uptake and biofilm formation by Bacillus subtilis A1/3. Mol. Genet. Genomics, 272: 363-378.

Kearns, D. B., Chu, F., Rudner, R. and Losick, R. 2004.Genes governing swarming in Bacillus subtilis and evidence for phase variation mechanism controlling surface motility.Mol. Microbiol., 52: 357-369.

Knapp, J. and Chandlee, J. M. 1996.Rapid, small-scale dual isolation of RNA and DNA from a single sample of orchid tissue.Biotechniques, 21: 54-55.

Leclere, V., Marti, R., Bechet, M., Fickers, P. and Jacques, P. 2006. The lipopeptides mycosubtilin and surfactin enhance spreading of Bacillus subtilis strains by their surface active properties. Arch. Microbiol., 186: 475-483.

Melody, S. C. 1997.Plant Molecular Biology - A laboratory manual. Springer-Verlag, NewYork.529 p.

Mikiciński, A., Sobiczewski, P., Puławska, J. and Maciorowski, R. 2016. Control of fire blight (Erwinia amylovora) by a novel strain 49M of Pseudomonas graminis from the phyllosphere of apple (Malus spp.). Eur. J. Plant Pathol., 145:265-276.

Msadek, T. 1999. When the going gets tough: survival strategies and environmental signaling networks in Bacillus subtilis. Trends Microbiol.,7: 201-207.

Narasimhan, A. and Shivakumar, S. 2015. Evaluation of Bacillus subtilis (JN032305) biofungicide to control chilli anthracnose in pot controlled conditions. Biocontrol Science and Technology, 25(5): 543-559.

Nihorimbere, V., Ongena, M., Smargiassi, M. and Thonart, P. 2011. Beneficial effect of the rhizosphere microbial community for plant growth and health. Biotechnol.Agron.Sociol.Environ., 15(2): 327-337.

O'Toole, G. A., Pratt, L. A., Watnick, P. I., Newman, D. K., Weaver, V. B. and Kolter, R. 1999. Genetic approaches to study of biofilms. Methods Enzymol., 310: 91-109.

Ongena, M. and Jacques, P. 2008. Lipopeptides: versatile weapons for plant disease biocontrol. Trends Microbiol., 16: 115125.

Rudrappa, T., Biedrzycki, M. L. and Bais, H. P. 2008. Causes and consequences of plantassociated biofilms. FEMS Microbiol. Ecol., 64: 153-166.

Saha, D., Purkayastha, G. D., Ghosh, A., Isha, M. and Saha, A. 2012.Isolation and characterization of two new Bacillus subtilis strains from the rhizosphere of eggplant as potential biocontrol agents. $J$. Plant Pathol.,94(1): 109-118.

Schneider, K. B., Palmer, T. M. and Grossman, A. D. 2002. Characterization of $\operatorname{com} Q$ and $\operatorname{com} X$, two genes required for production of ComX pheromone in Bacillus subtilis. J. Bacteriol., 184: 410419.

Tortosa, P. and Dubnau, D. 1999. Competence for transformation: a matter of taste. Curr.Opin.Microbiol, 2: 588-592.

Tortosa, P., Logsdon, L., Kraigher, B., Itoh, Y., MandicMulec, I. and Dubnau, D. 2001. Specificity and genetic polymorphism of the Bacillus competence quorum sensing system. J. Bacteriol, 183: 451-460.

\section{How to cite this article:}

Smitha, K.P., E. Rajeswari, D. Alice and Raguchander, T. 2017. Exploring Quorum Sensing Loci and Biofilm Formation in Bacillus Isolates from Pigeonpea Rhizosphere. Int.J.Curr.Microbiol.App.Sci. 6(11): 3252-3262. doi: https://doi.org/10.20546/ijcmas.2017.611.381 